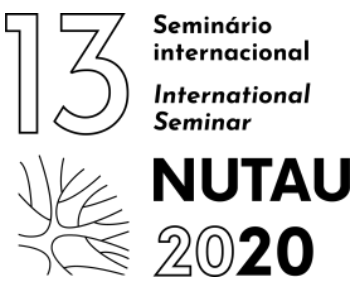

\title{
Urbsistemas:
}

\section{Uma abordagem sistêmica para cidades sustentáveis, eficientes e resilientes}

\author{
Marcos Silveira Buckeridge \\ Centro de Síntese USP-Cidades Globais / IEA USP, Professor Livre-Docente \\ msbuck@usp.br
}

\section{RESUMO}

A evolução das cidades é vista como tendo seu aparecimento relacionado ao desenvolvimento da agricultura, o que possibilitou maior estabilidade aos agrupamentos de seres humanos. Tal estabilidade foi atraindo cada vez mais pessoas, uma vez que, viver no ambiente urbano traz diversas vantagens, como menor custo de vida, proteção contra inimigos, entre outras. Apesar de apropriada e de definir bem um dos princípios que levaram à formação de assentamentos humanos, esta é uma visão fortemente economicista. Nesta palestra eu apresento uma visão alternativa da evolução das cidades. Nesta visão, a cidade é vista com base em seu funcionamento, ou seja, na fisiologia urbana. Vejo a cidade como um urbsistema, um processo que, como os ecossistemas, possui um mecanismo central, a cidade em si e seus processos, alimentado por materiais, água e energia e cujo funcionamento gera resíduos. O urbsistema é um conceito funcional em que os elementos trabalhando em conjunto formam um subsistema urbano primário (SUP), dentro do qual funciona o subsistema urbano secundário (SUS), que se articula através da interconexão em rede de um conjunto de elementos funcionais menores denominados subsistemas urbanos terciários (SUT). Dentre estes últimos figuram os sistemas educacional, de saúde, meio ambiente, mobilidade, habitação, assistência social, entre outros. A eficiência no funcionamento e o grau de articulação entre os SUT conferem ou não harmonia aos níveis hierárquicos superiores e consequentemente ao urbsistema, determinando o seu nível de sustentabilidade. Assim, quanto maior a sustentabilidade de um urbsistema, mais estáveis e funcionais são seus SUT, SUS e SUP. Ao ser atingido por uma intempérie, o grau de penetração através desses níveis hierárquicos definirá a resiliência do urbsistema, ou seja, quanto mais resiliente, menos este urbsistema sofrerá com o impacto e se recuperará mais rápido. Para demonstrar como a complexidade se relaciona com a estabilidade do urbsistema, examinarei dois casos de intempéries que atingiram a cidade de São Paulo: a pandemia da COVID-19 e a seca de 2014. Ao propor uma solução para aumentar a resiliência das cidades aos impactos de intempéries, mostrarei o Guia para Cidades Sustentáveis, que apresenta um conjunto de 193 itens de agenda para candidatos a cargos eletivos e gestores de cidades com o objetivo de auxiliar a trilhar o caminho para a sustentabilidade urbana. 0 argumento principal é que, com políticas públicas baseadas em conhecimento científico e gestão sistêmica visando a sustentabilidade, podemos tornar as nossas cidades muito mais eficientes e resilientes.

Palavras-chave: cidades globais, sistemas urbanos, sustentabilidade.

\section{ABSTRACT}

The evolution of cities is seen as having its appearance related to the development of agriculture, which allowed greater stability to groups of human beings. This stability has attracted more and more people, since living in the urban environment brings several advantages, such as lower cost of living, protection against enemies, among others. Despite being appropriate and defining one of the principles that led to the formation of human settlements, this is a strongly economist view. In this lecture I present an alternative view of the evolution of cities. In this view, the city is seen based on its functioning, that is, on urban physiology. I see the city as an urbsystem, a process that, like ecosystems, has a central mechanism, the city itself and its processes, fed by materials, water and energy and whose operation generates waste. The urbsystem is a functional concept in which the elements working together form a primary urban subsystem (SUP), within which the secondary urban subsystem (SUS) works, which is articulated through the network interconnection of a set of smaller functional elements called tertiary urban subsystems (SUT). Among the latter are educational, health, environment, mobility, housing, social assistance systems, among others. Efficiency in operation and the degree of articulation between the SUT provide harmony or not to the higher hierarchical levels and consequently to the urbsystem, determining its level of sustainability. Thus, the greater the sustainability of an urbsystem, the more stable and functional its SUT, SUS and SUP are. When hit by an inclement weather, the degree of penetration through these hierarchical levels will define the resilience of the urbsystem, that is, the more resilient, the less this urbsystem will suffer from the impact and recover faster. To demonstrate how complexity relates to the stability of the urbsystem, I will examine two cases of bad weather that hit the city of São Paulo: the COVID-19 pandemic and the 2014 drought. By proposing a solution to increase cities' resilience to impacts of weather, I will show you the Guide to Sustainable Cities, which presents a set of 193 agenda items for candidates for elective positions and city managers in order to help pave the way for urban sustainability. The main argument is that, with public policies based on scientific knowledge and systemic management aimed at sustainability, we can make our cities much more efficient and resilient.

Keywords: global cities, urban systems, sustainability. 